\title{
PROSES PERANCANGAN BUKU VECTOR RAGAM HIAS WAYANG GAGRAK SURAKARTA
}

\author{
Lintang Widyokusumo \\ Visual Communication Design, School of Design, BINUS University \\ Jln. K.H. Syahdan No. 9, Palmerah, Jakarta Barat 11480 \\ lintangw@binus.edu
}

\begin{abstract}
In the early stages of gagrak puppet ornaments book designing of Surakarta, digitally process documentation is done. Source images with poor conditions are transferred through the tracing process that requires precision to produce documentation of images with sharp vector format. Diversity of gagrak puppet ornaments and accessories are tried to be compiled in a book with a grid system that is expected to be a reference book of attractive gagrak puppets ornaments in a contemporary appearance. Article is based on a literature review by selecting multiple sources of both printed and electronic and doing some sketches of various shapes observation, shapes and textures. A collection of ornaments in the notion that is processed from the 'old values' that have been there that will be applied to 'new value' a masterpiece of design that can be universally accepted and globally
\end{abstract}

Keywords: book, ornament, shadow puppet

\begin{abstract}
ABSTRAK
Pada tahapan awal sebuah perancangan buku ragam hias wayang gagrak Surakarta, dilakukan proses dokumentasi secara digital. Sumber gambar dengan kondisi cetakan yang buruk ditransfer melalui proses tracing yang membutuhkan ketelitian tersendiri untuk menghasilkan dokumentasi gambar dengan format vector yang tajam. Keragaman ragam hias dan asesori wayang gagrak ini dicoba untuk disusun dalam sebuah buku dengan sistem grid sehingga diharapkan dapat menjadi buku acuan ragam hias wayang gagrak yang menarik dalam tampilan kekinian. Artikel disusun berdasarkan studi pustaka yaitu menyeleksi beberapa sumber referensi baik tercetak maupun elektronik dan melakukan beberapa observasi sketsa berbagai bentuk, bidang, tekstur. Sebuah kumpulan ragam hias dalam gagasan yang diolah dari 'nilai-nilai lama' yang telah ada yang nantinya akan diaplikasikan menjadi 'nilai baru' sebuah karya desain yang dapat diterima secara universal dan global.
\end{abstract}

Kata kunci: buku, ornamen, wayang 


\section{PENDAHULUAN}

Wayang adalah salah satu bentuk teater tradisional yang ada di Indonesia. Walaupun ada dua pendapat yang menyatakan wayang adalah kebudayaan asli Indonesia namun ada juga pendapat yang mengatakan bahwa wayang juga berasal dari India, namun sejak tahun 1950an banyak literatur yang sepakat mengatakan bahwa wayang adalah kebudayaan asli Indonesia (Soetrisno, 2008). Kesenian wayang adalah suatu bentuk seni teater di mana istilah wayang berasal dari bayang-bayang, di mana dalam bahasa jawa berarti bayangan atau imajinasi juga dikonotasikan sebagai roh. Kesenian ini telah diakui dunia Internasional sebagai a Masterpice of Oral and Intangible Heritage of Humanity oleh UNESCO pada tanggal 7 November 2003.

Pertunjukan pergelaran Wayang dikenal di pulau jawa sejak 1500 SM. Semasa kerajaan Kediri, Singasari dan Majapahit. Saat itu pertunjukan wayang hanya dilakukan berdasarkan permintaan kerajaan, sejak itulah maka pertunjukan pergelaran wayang berlangsung hingga kini. Cerita yang dibawakan berasal dari Ramayana dan Mahabarata. Begitu kuatn seni wayang yang berakar dari dari kebudayaan Indonesia, maka terjadilah kerancuan antar cerita wayang, legenda dan sejarah. Banyak masyarakat yang beranggapan bahwa cerita-cerita pewayangan tersebut benar-benar terjadi di pulau jawa. Perkembangan wayang selama berabad-abad menjadikan berbagai jenis wayang yang kisahnya tetap menggunakan epos Ramayana dan Mahabarata. Media penyampaiannya pun beragam mulai dari rumput, kertas/karton, kayu, kain, kulit bahkan wayang orang (Soetrisno, 2004).

Perkembangan jenis wayang biasanya dipengaruhi perkembangan dari budaya setempat, misalnya wayang kulit purwa berkembang sesuai daerah masing-masing seperti wayang kulit purwa khas Cirebon, Bali, Banjar dan lain-lain. Keindahan tatahan wayang didukung pula dengan lukisan ragam hias yang tergambar dalam figur-figur wayang merupakan karya agung yang tidak hanya cantik dalam komposisi asesoris namun juga pesan-pesan simbolis yang disampaikan dalam bentuk-bentuk tersebut.

Bahasa rupa dalam seni ragam hias wayang masuk dalam kategori bahasa rupa tradisi, yang menggunakan system penggambaran ruang waktu datar (RWD) meskipun gambar bersifat datar (dua dimensi) namun mampu merepresentasikan dimensi gerak dan waktu di dalamnya, sehingga bukanlah gambar diam (Piliang, 2006). Dengan upaya pengembangan seni Pewayangan saat ini tentunya membuahkan hasil yang menggembirakan dan membanggakan.Wayang menjadi seni yang bermutu tinggi (adiluhung), mampu menyampaikan pesan-pesan moral keutamaan hidup. Fungsi dan peranan media pergelaran wayang tetap terus berlanjut hingga saat ini.

\section{METODE}

Artikel disusun berdasarkan studi pustaka yaitu menyeleksi beberapa sumber referensi baik tercetak maupun elektronik dan melakukan beberapa observasi sketsa berbagai bentuk, bidang, tekstur kemudian informasi tersebut dirangkum dan ditransfer dalam format digital untuk kemudian disusun dalam tata letak buku ragam hias wayang yang sistematis dan menarik secara visual. 


\title{
HASIL DAN PEMBAHASAN
}

\section{Proses Perancangan Kerangka Buku}

Dalam proses perancangan buku Ragam Hias Wayang ini seperti dalam rencana tahapan kerja difokuskan pada proses digitalisasi ragam hias yang sudah diperoleh datanya pada penelitian tahap pertama. Proses kerja dimulai dengan seleksi ragam hias yang akan ditampilkan dalam prototype buku vector tersebut. Penyusunan daftar isi sebagai kerangka buku dapat mempermudah pemetaan bab demi bab yang akan diulas dalamnya. Adapun kerangka daftar isi tersebut adalah:

\section{Kover Buku}

\section{Daftar Isi}

\section{Pendahuluan}

\section{Anatomi Wayang}

Ragam Hias bentuk Mata Wayang

Ragam Hias Bentuk Hidung

Ragam Hias Gelung Rambut Wayang Pria

Ragam Hias Gelung Rambut Wayang Wanita

\section{Aplikasi Asesori Busana}

\author{
Ragam Hias Jamang \\ Ragam Hias Garuda Mungkur \\ Ragam Hias Irah-Irahan \\ Ragam Hias Kalung dan Kelat Bahu \\ Ragam Hias Gelang \\ Ragam Hias Sumping
}

\section{Galeri}

Asesori Busana Wayang Pria

Asesori Busana Wayang Wanita

Pengembangan Inspirasi Ragam Hias

\section{Desain Grid}

Adapun setelah menentukan format buku maka ukuran buku ditentukan sebesar A4 (29.7 x 21 $\mathrm{cm}$ ). Desain grid (garis bantu tata letak) ditentukan menggunakan jenis grid dua kolom dengan dua halaman (spread page) saling berhadapan (miror image margin). Jenis grid kolom ini bersifat sangat fleksibel dan dapat digunakan untuk menyatukan beberapa macam elemen dan informasi dalam sebuah layout. Adapun kegunaan dari penggunaan Grid adalah untuk menciptakan unity/keseragaman setiap halaman dalam sebuah buku dan menciptakan struktur dari sebuah layout/tata letak sehingga menbantu desainer untuk menciptakan keseimbangan dalam eksplorasi sebuah desain (Samara, 2002). 
Surakarta.

Berikut adalah desain grid yang dipakai dalam perancangan buku ragam hias wayang gagrak

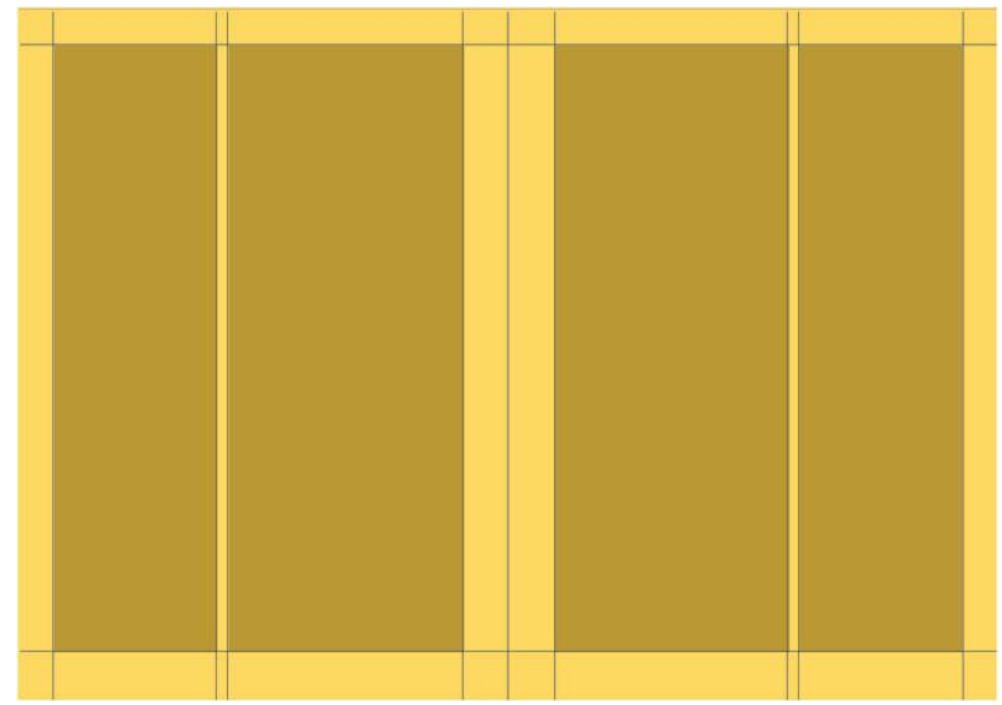

Gambar 1 GRID desain dua kolom menjadi kerangka dasar proses tata letak buku vector ragam hias.

Sumber: Dokumentasi tim peneliti

\section{Proses Digitalisasi Gambar}

Setelah perancangan grid dilakukan, maka tahapan berikutnya adalah tahap pemindaian semua sumber gambar dari hasil dokumentasi beberapa buku dan studi lapangan melalui media alat pindai/scanner dan piranti lunak Adobe Photoshop. Kendala kecilnya ukuran sumber gambar yang ada cukup menyulitkan dalam proses digitalisasi ini mengingat dalam tahap proses tracing untuk format vector maka hasil pindai akan terlihat pecah pada layar (low resolution). Format vector mempunyai kelebihan tersendiri dibanding gambar dengan format bitmap. Format vector merupakan gambar digital yang berbasis persamaan hitungan matematis. Beberapa format vector seperti $E P S, A I, C D R$ dan sebagainya. Hasil gambar yang dihasilkan oleh format ini tidak akan menjadi pecah apabila melalui proses pembesaran, karena gambar vector terdiri dari penggabungan garis dan titik.

Berbeda dengan bitmap, gambar yang dihasilkan dari citra grafis yang terdiri dari beberapa titik yang tersimpan dalam data komputer atau dikenal dengan pixel. Kerapatan antar titik tersebut ditentukan oleh resolusi, semakin besar resolusi semakin baik kualitas gambar ketika dicetak. Minimal resolusi yang baik untuk dicetak adalah 300px/inch. Beberapa format bitmap adalah TIFF, JPEG, GIF dll. Menimbang hal tersebut maka tim peneliti memutuskan untuk memakai format vector dalam pengerjaan buku ragam hias ini agar tercapai hasil grafis yang tajam dan mudah pada aplikasinya.

Setelah gambar dipindai dan disimpan dalam format $J P E G$, maka gambar-gambar ragam hias tersebut dapat mulai di-tracing dengan menggunakan Adobe Illustrator untuk menghasilkan gambar vector. Tahapan proses ini dapat dikatakan cukup sulit mengingat banyak detail ragam hias dalam gambar aslinya dengan kualitas resolusi yang buruk. Proses tracing gambar yang diimport pada piranti lunak Adobe Illustrator diletakkan pada layer yang berbeda kemudian mengaktifkan fungsi lock pada layer sehingga gambar master tidak akan terseleksi. Dimulailah proses tracing dengan menggunakan pen tool. 


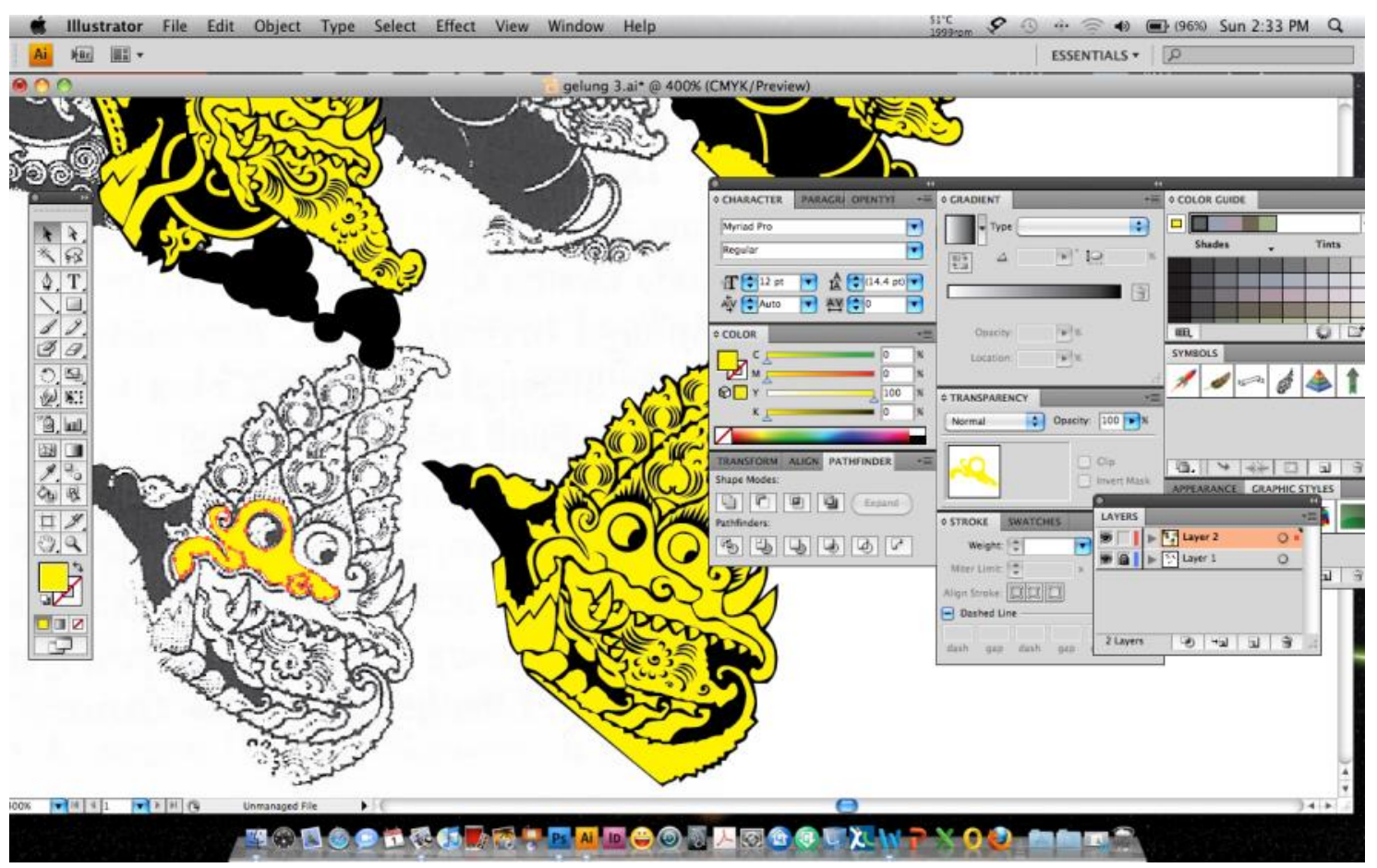

Gambar 2 Tahap digitalisasi di mana setelah sumber gambar dipindai lalu proses tracing dimulai menggunakan Adobe Illustrator dalam format vector. Sumber: Dokumentasi tim peneliti

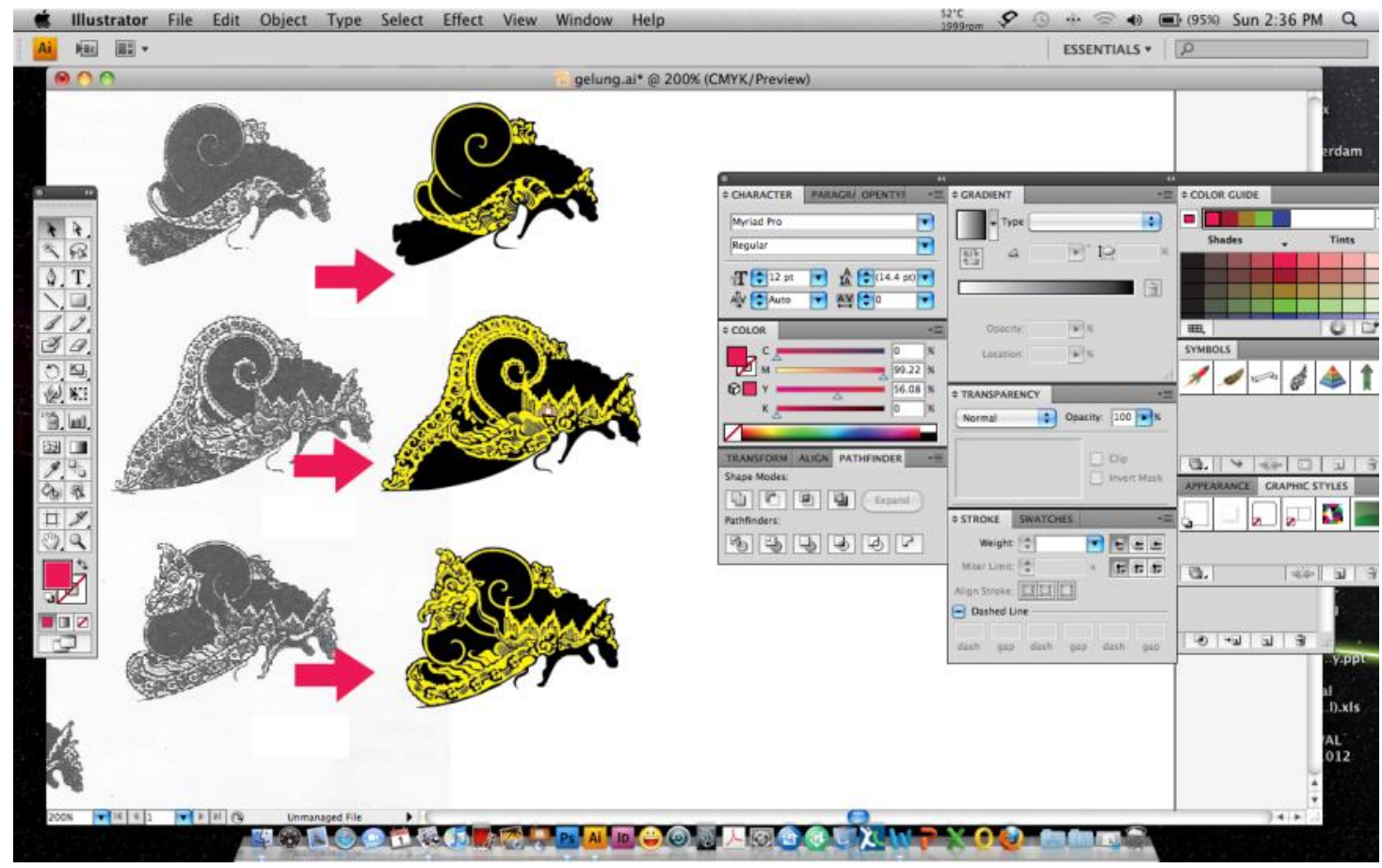

Gambar 3 Hasil tracing dengan piranti lunak Adobe Illustrator format vector terlihat lebih tajam walaupun gambar diperbesar dan lebih mudah untuk diberi warna. Sumber: Dokumentasi tim peneliti. 


\section{Proses Perancangan Namestyle Buku Ragam Hias}

Pada proses perancangan namestyle ini ditentukan judul yang sesuai namun cukup ringkas untuk diingat, maka terpilihlah judul buku dengan kalimat "Ragam Hias Wayang Gagrak Surakarta". Hirarki bacaan namestyle tersebut memberikan penekanan pada kata "Wayang" lalu kata "Ragam Hias" dan hirarki terakhir adalah "Gagrak Surakarta". Hirarki keterbacaan namestyle diperoleh dari penekanan kata dengan membedakan besar huruf/point size serta komposisi peletakan namestyle tersebut. Dalam perancangan ini dipilih jenis huruf serif (berkait) Birch Standard yang berkarakter elegan namun modern dan dapat mewakili karakter wayang dalam nafas kekinian.

Dalam rancangan yang memberikan keseimbangan kekinian yang lebih menonjol maka dipilih complementary typeface Eurostile sebagai jenis huruf untuk tagline"gagrak Surakarta". Agar namestyle buku ini mempunyai karakter tersendiri, maka dibutuhkan beberapa modifikasi dalam aplikasinya dengan menarik beberapa anatomi huruf menjadi ragam hias sulur-suluran yang dipadukan dengan beberapa bagian kecil ragam hias wayang. Pada akhirnya terciptalah namestyle yang unik dan berkarakter khas buku ragam hias wayang ini.

Untuk running head buku ragam hias ini memakai jenis huruf Birch Std, namun untuk headline (judul bab) menggunakan kombinasi jenis huruf Birch Std dan Eurostile. Pada bodytext dan caption digunakan jenis huruf sanserif yaitu Calibri yang berkarakter modern.

Birch Std

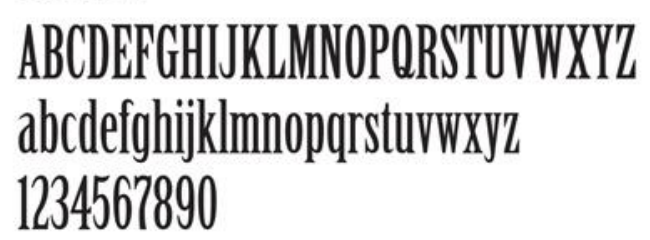

Eurostile

ABCDEFGHIJKLMNOPQRSTUVWXYZ

abcdefghijklmnopqrstuvwxyz

1234567890

Calibri

ABCDEFGHIJKLMNOPQRSTUVWXYZ abcdefghijklmnopqrstuvwxyz 1234567890

Gambar 4 Speciment keluarga huruf Birch Std, Eurostile dan Calibri yang dipakai dalam perancangan buku ragam hias ini.

Sumber: Dokumentasi tim peneliti. 


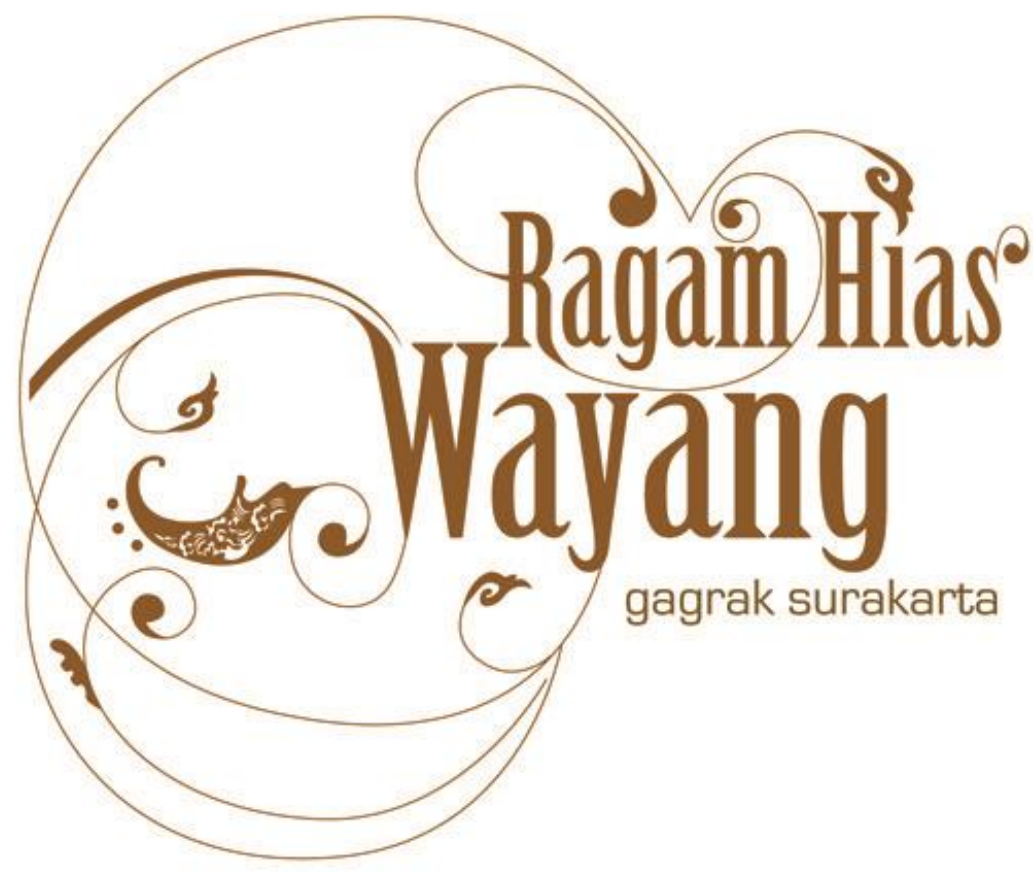

Gambar 5 Desain Namestyle buku Ragam Hias Wayang Gagrak Surakarta Sumber: Dokumentasi tim peneliti.

\section{Perancangan Kover dan Daftar Isi Buku Ragam Hias Wayang}

Setelah mendapatkan desain namestyle yang sesuai maka dimulai untuk perancangan kover yang menarik untuk sebuah buku ragam hias. Tentunya faktor namestyle yang menarik akan mempengaruhi sebuah desain kover buku. Untuk sebuah kover buku ragam hias yang menarik tentunya akan lebih menarik menampilkan beberapa contoh desain yang terdapat di dalam buku. Menimbang hal tersebut, maka dipilih sebuah desain kover buku ragam hias yang cukup banyak menampilkan beberapa contoh ragam hias gelung dan irah-irahan wayang yang variatif. Dari sini akan tercapai sebuah kover yang menarik untuk dilihat dan juga menampilkan keragaman seni kriya ragam hias yang detail dan indah.

Warna biru gelap dipilih agar menciptakan mood elegan namun tidak over powering sehingga dapat menonjolkan keindahan ilustrasi menciptakan hirarki antar elemen desain yang ditampilkan. Pada sisi kanan diberikan sedikit aksen tumpal yang diambil dari ragam hias kain jawa. Namestyle diletakkan pada posisi tengah namun merapat pada sisi kanan agar tidak berkesan simetris dan diberi warna orange kekuningan agar terlihat kontras dengan latar sehingga mudah untuk dibaca dari kejauhan. Berikut adalah hasil desain akhir kover buku tersebut. 


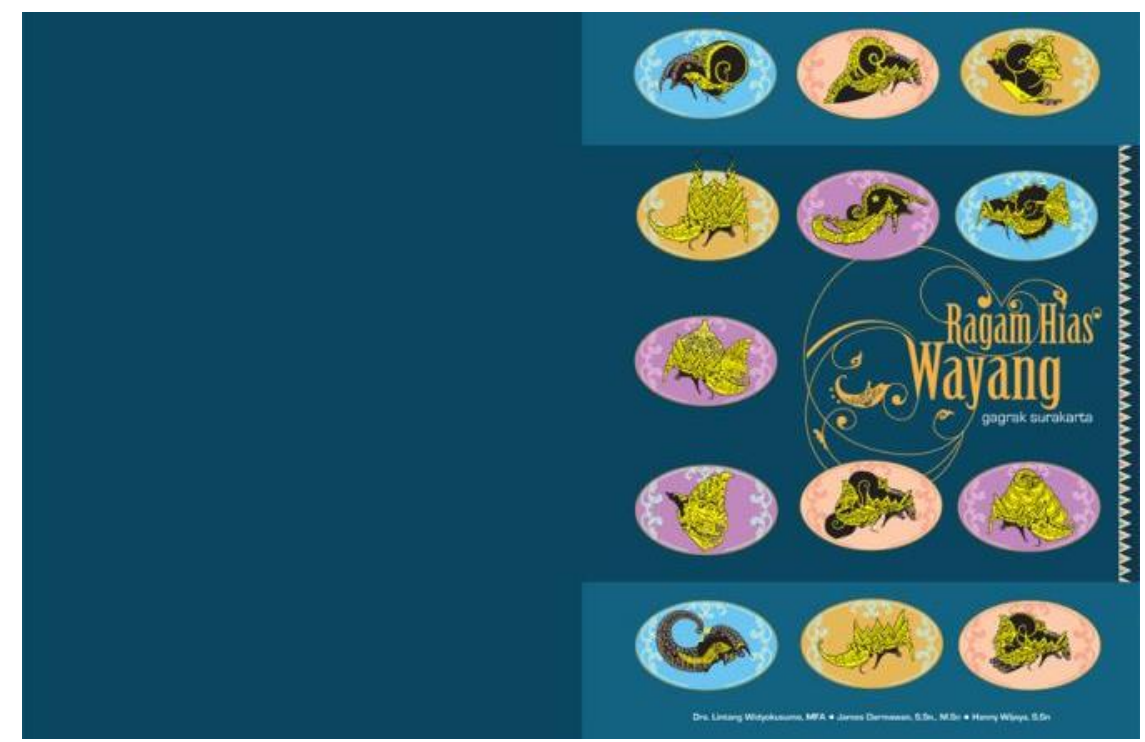

Gambar 6 Kover Desain Buku Ragam Hias Wayang Gagrak Surakarta.

Sumber: Hasil perancangan tim peneliti.

Desain daftar isi dirancang simpel dengan tujuan memberikan efek surprise bila pembaca membuka halaman selanjutnya yang sudah ramai dengan visualisasi ragam hias wayang yang penuh corak dan warna. Warna kuning dipilih karena pembaca akan lebih mudah untuk membaca pada halaman ini untuk mencermati halaman mana yang akan dibuka. Aksen cukup menggunakan namestyle dari buku tersebut karena cukup unik untuk menjadi pusat perhatian dalam halaman ini. Susunan daftar isi dibuat lebih bersusun mengikuti kolom agar terlihat clean dan modern untuk memberi keseimbangan pada namestyle yang dekoratif. Jenis huruf tetap memakai Birch Std dan Eurostyle sebagai kepatuhan akan sistem buku ini.

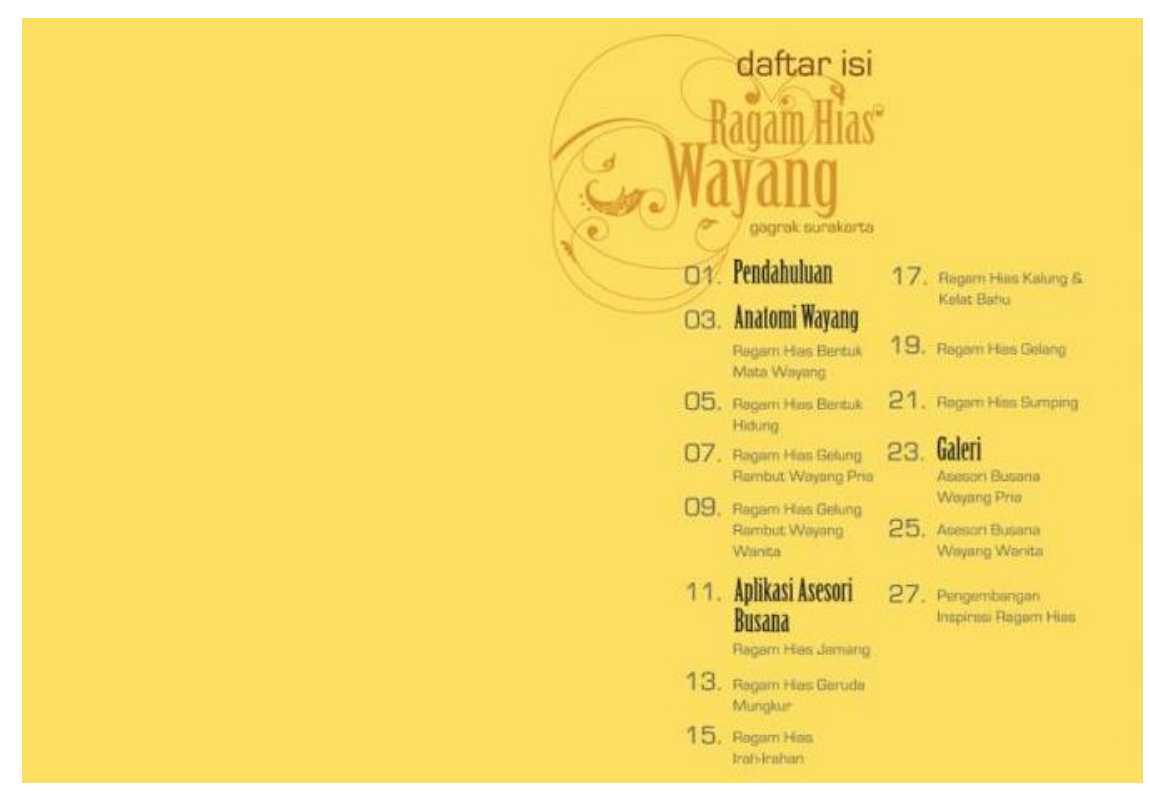

Gambar 7 Hasil rancangan halaman daftar isi buku ragam hias. Sumber: hasil perancangan tim peneliti. 


\section{Halaman Pendahuluan}

Halaman pendahuluan memberikan gambaran singkat mengenai jenis-jenis wayang kulit purwa gagrak Surakarta seperti berikut:

Wayang Bokongan, adalah wayang yang bentuk pantat dibuat bulat atau lonjong seperti Arjuna dan Kresna.

Wayang Jangkahan, ada dua macam jangkah (langkah) yaitu (1) Jangkah Wiyar, yaitu wayang dengan langkah lebar dan (2) Jangkah Ciyut, yaitu wayang dengan langkah kecil.

Wayang Brongsong, semua jenis wayang yang wajahnya diwarna prada.

Wayang Lanyapan, adalah semua jenis wayang dengan kepala mendongak/menengadah.

Wayang Longok, adalah wayang dengan kepala tidak terlalu mendongak dan juga menunduk.

Wayang Luruh, adalah semua wayang dengan kepala menunduk.

Wayang $\boldsymbol{O y i}$, adalah semua wayang wanita yang menunduk.

Wayang Endel, adalah semua wayang wanita yang mendongak.

Wayang Gusen, adalah wayang yang kelihatan gusi dan taringnya.

Pada halaman ini diberikan gambar contoh anatomi wayang Arjuna sebagai wayang bokongan kemudian jenis gelung rambut yang dipakai yaitu Supit Urang, jenis mata yaitu Gabahan, motif busana yang dipakai (motif Semen Ningrat) serta manggaran seperti simpul yang dikenakan pada bagian belakang wayang. Pada kiri dan kanan halaman diberikan sedikit aksen ragam hias wayang untuk mempercantik desain tata letak secara keseluruhan.

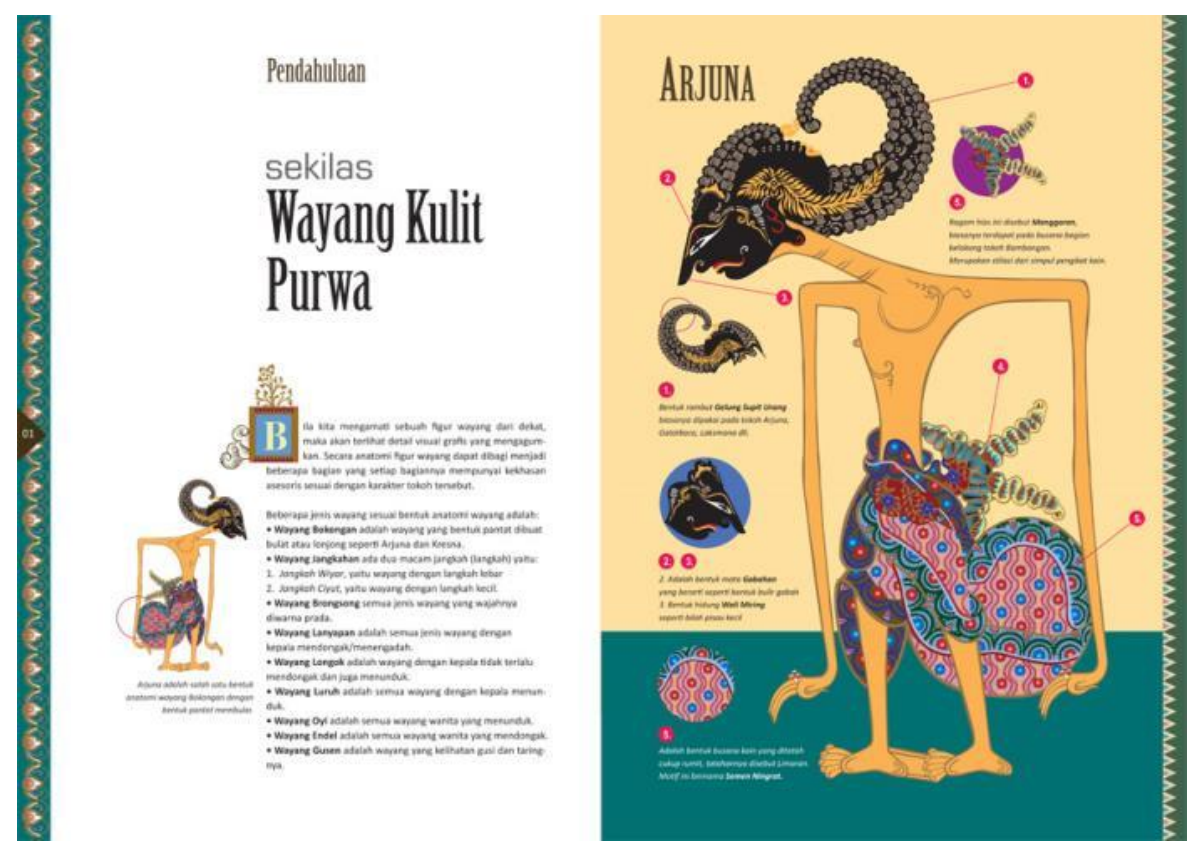

Gambar 8 Halaman Pendahuluan menjelaskan secara singkat jenis-jenis wayang kulit purwa.

Sumber: Hasil perancangan tim peneliti. 


\section{Halaman Anatomi Wayang (Ragam Hias Bentuk Mata Wayang)}

Pada rancangan halaman berikutnya adalah memasuki bab Anatomi Wayang ini maka pembahasan dimulai dengan ragam hias bentuk mata wayang seperti:

Gabahan, berbentuk seperti gabah. (biasanya mata ini digunakan tokoh diantaranya Arjuna dan semua bambangan, Kresna dan tokoh putri lainnya, menggambarkan watak wayang dengan tingkah laku halus, tajam, tangguh dan trampil dalam berperang).

Kedhelen, berbentuk seperti biji kedelai (biasanya dipakai pada tokoh-tokoh peraga seperti Baladewa, Setyaki dan patih Udawa, menggambarkan watak wayang dengan tingkah laku tangguh dan trengginas).

Kedhondhongan, berbentuk seperti buah kedondong (biasanya dipakai pada tokoh-tokoh wayang seperti Patih Sengkuni, Kartamarma, menggam,barkan watak wayang dengan tingkah laku lincah namun sering melakukan tindakan tidak baik).

Penanggalan, berbentuk seperti bulan sabit (menggambarkan watak wayang yang selalu curiga dan meremehkan orang lain. Biasanya dipakai pada tokoh Buta Cakil, juga pada tokoh Batara Narada dan Drona).

Kelipan, mata setengah menutup biasanya dipakai pada tokoh raksasa namun Semar juga memakai jenis mata ini. (menggambarkan watak wayang jenaka dan ramah).

Telengan, bentuk mata ini seperti melotot, semua bola mata terlihat bulat (tokoh seperti Bima dan Duryudana memakai jenis mata ini termasuk beberapa jenis raksasa mempunyai perilaku tangguh, menakutkan bila marah dan berbahaya).

Plelengan, bentuk mata ini lebih melotot lagi dibanding mata Telengan, hampir semua raksasa besar memakai bentuk mata ini (mempunyai karakter suka memaksa dan teledor).

Plolon, bentuk mata yang seolah tidak mempunyai kelopak mata, beberapa tokoh yang menggunakan ini adalah Togog dan Bagong (mempunyai karakter lugu, apa adanya dan jenaka) (Wangi, 2009).

Pada halaman ini juga diberi ilustrasi tokoh Semar sebagai salah satu tokoh wayang yang memakai ragam hias Kelipan yang menggambarkan karakter ramah dan jenaka.
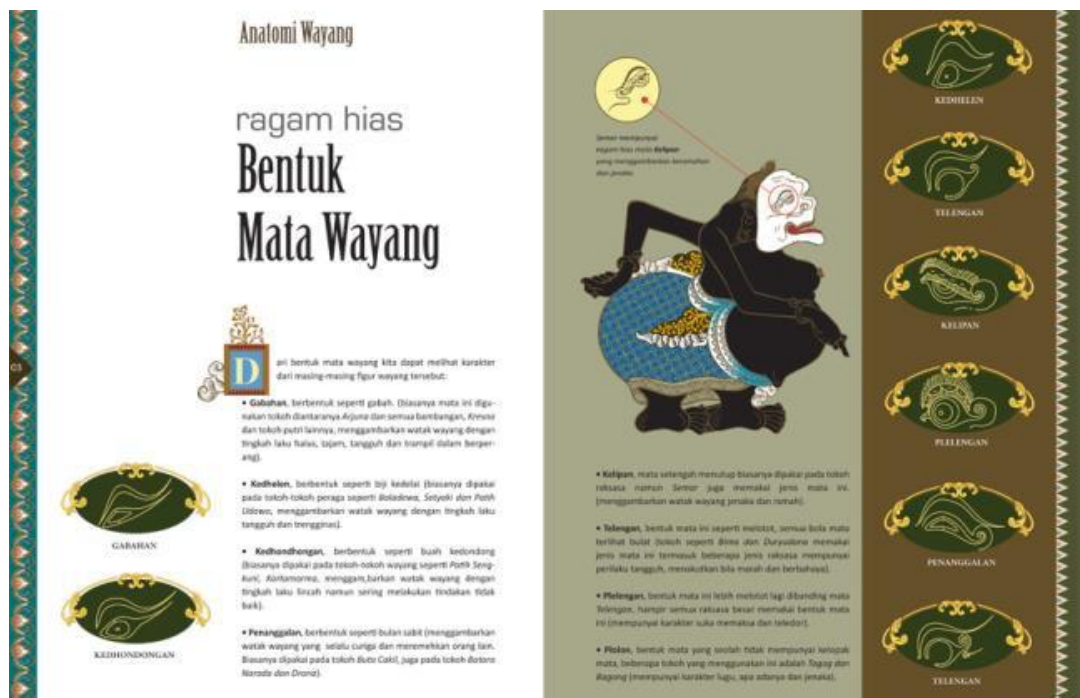

Gambar 9 Bab anatomi wayang yang membahas ragam hias mata wayang. Sumber: Hasil perancangan tim peneliti 


\section{Halaman Anatomi Wayang (Ragam Hias Bentuk Hidung Wayang)}

Pada rancangan halaman berikutnya adalah memasuki bab Anatomi Wayang ini maka pembahasan dimulai dengan ragam hias bentuk hidung wayang seperti:

Wali miring, hidung seperti ujung pisau dapur (biasanya untuk wayang bertubuh kecil atau putri)

Bentulan, hidung berbentuk seperti ujung golok.Diberi namaBentulan karena bentuk ini menyerupai bentul atau buah Soka.Contoh pada tokoh wayang Duryudana, Gandamana, dan Kartamarma.

Pangotan, hidung berbentuk seperti pisau untuk meraut kayu.Contoh tokoh wayang yang memiliki bentuk hidung ini adalah Indrajit dan Kangsa.

Pelokan, hidung menyerupai bentuk mangga, biasanya untuk tokoh-tokoh raksasa dalam pewayangan seperti Kumbakarna, Suratimantra dan Prabu Arimba.

Bruton, hidung berbentuk menyerupai ekor ayam/brutu.Tokoh wayang yang memiliki bentuk hidung ini adalah Bagong dan Batara Patuk.

Sumpel, hidung yang melesak ke dalam/pesek, sehingga tidak mempunyai tonjolan hidung.Adapun tokoh wayang yang memiliki bentuk hidung ini adalah Semar dan Limbuk.

Terong Glatik, hidung berbentuk seperti terung gelatik, contohnya pada tokoh Gareng.

Campeluk, bentuk hidung memanjang seperti buah asam, bentuk khas ini dimiliki oleh tokoh wayang Petruk.

Terong Kopek, hidung bulat menggantung seperti buah terung

Pisekan, mirip seperti hidung sumpel

Nyantik Palwa/Nyantik Prau, bentuk hidung ini digunakan untuk bentuk hidung Kumbakarna, Niwatakawaca dan Batara Kala. (Wangi, 2009)

Beberapa bentuk jenis hidung tersebut diberikan ilustrasi sebagai contoh aplikasi pada tokoh wayang tertentu.

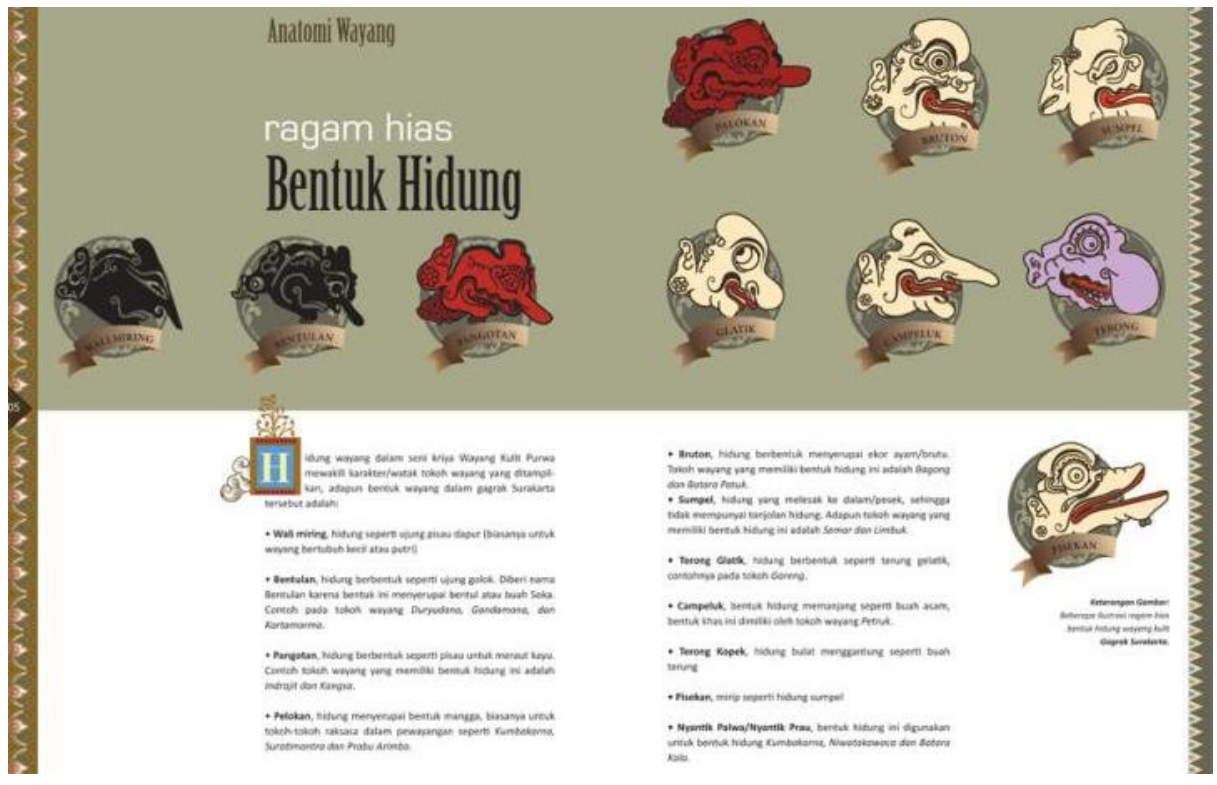

Gambar 10 Bab anatomi wayang yang membahas ragam hias hidung wayang.

Sumber: Hasil perancangan tim peneliti 


\section{Halaman Anatomi Wayang (Ragam Hias Gelung Rambut Wayang Pria)}

Pada halaman bab Anatomi Wayang ini dimulai pembahasan ragam hias bentuk gelung rambut wayang pria seperti:

Gelung Cupit Urang, adalah gelung yang biasanya dikenakan oleh Arjuna, Gatotkaca, Nakula, Sadewadll.Jenis ini ada yang polos, namun ada juga yang memakai jamang.

Gelung Keling, adalah gelung yang biasa dikenakan oleh Yudistira, prabu Drupada, Gandamana dll. Jenis inipun ada yang polos, namun ada pula yang memakai jamang

Gelung Gembel, adalah gelung untuk tokoh wayang berambut ikal.

Gelung Bundel, mirip dengan gelung bundle, jenis ini diperuntukkan untuk wayang dengan rambut ikal/keriting.

Gelung Pogok Lungsen, ada dua jenis yaitu memakai jamang dan polosan.

Gelung Pogok tanpa Lungsen, ada dua jenis yaitu memakai jamang dan polosan (Wangi, 2009)

Halaman ini dipakai thema warna biru yang identik dengan warna pria.Pada masing-masing ilustrasi diberi panel elips dengan sedikit ornamen ragam hias yang memperindah frame masingmasing ilustrasi gelung rambut. Masing-masing panel diberikan stilasi bendera untuk meletakkan informasi nama jenis gelung tersebut.

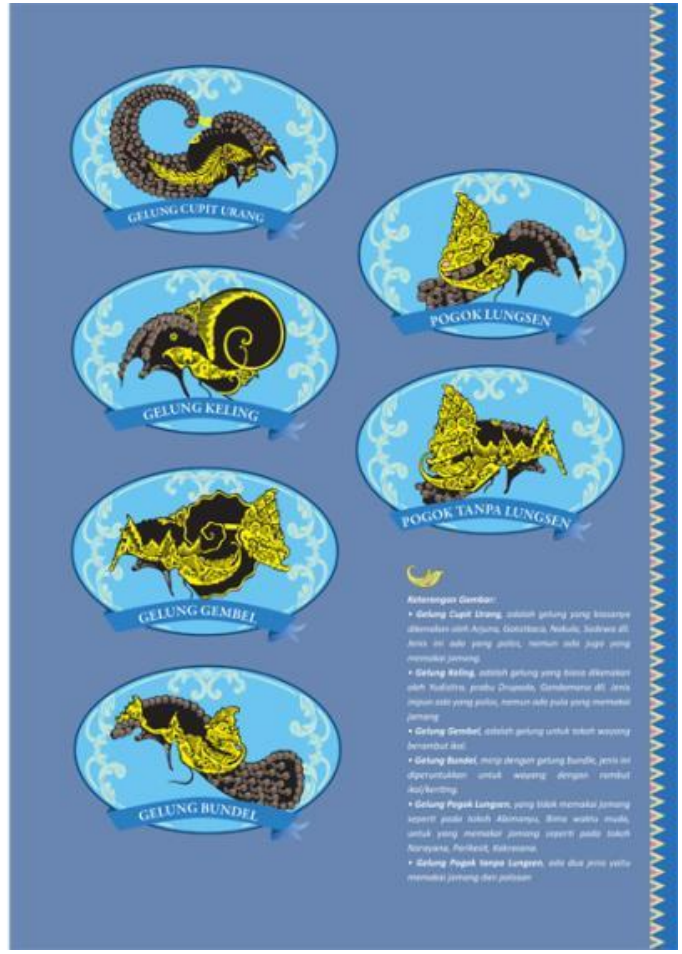

Gambar $11 \mathrm{Bab}$ anatomi wayang yang membahas ragam hias gelung wayang pria. Sumber: Hasil perancangan tim peneliti 


\section{Halaman Anatomi Wayang (Ragam Hias Gelung Rambut Wayang Wanita)}

Pada halaman selanjutnya masih pada bab Anatomi Wayang ini dimulai pembahasan ragam hias bentuk gelung rambut wayang wanita seperti:

Gelung Ukel Keyongan, gelung ini banyak dikenakan tokoh wayang wanita.

Gelung Kembang, gelung dengan stilasi hiasan bunga di rambut

Gelung Endel, gelung yang dihiasi garuda mungkur

Gelung Malang, gelung berbentuk melintang

Gelung Ageng, serupa dengan gelung ukel namunmemakai hiasan garuda mungkur berukuran besar. (Wangi, 2009)
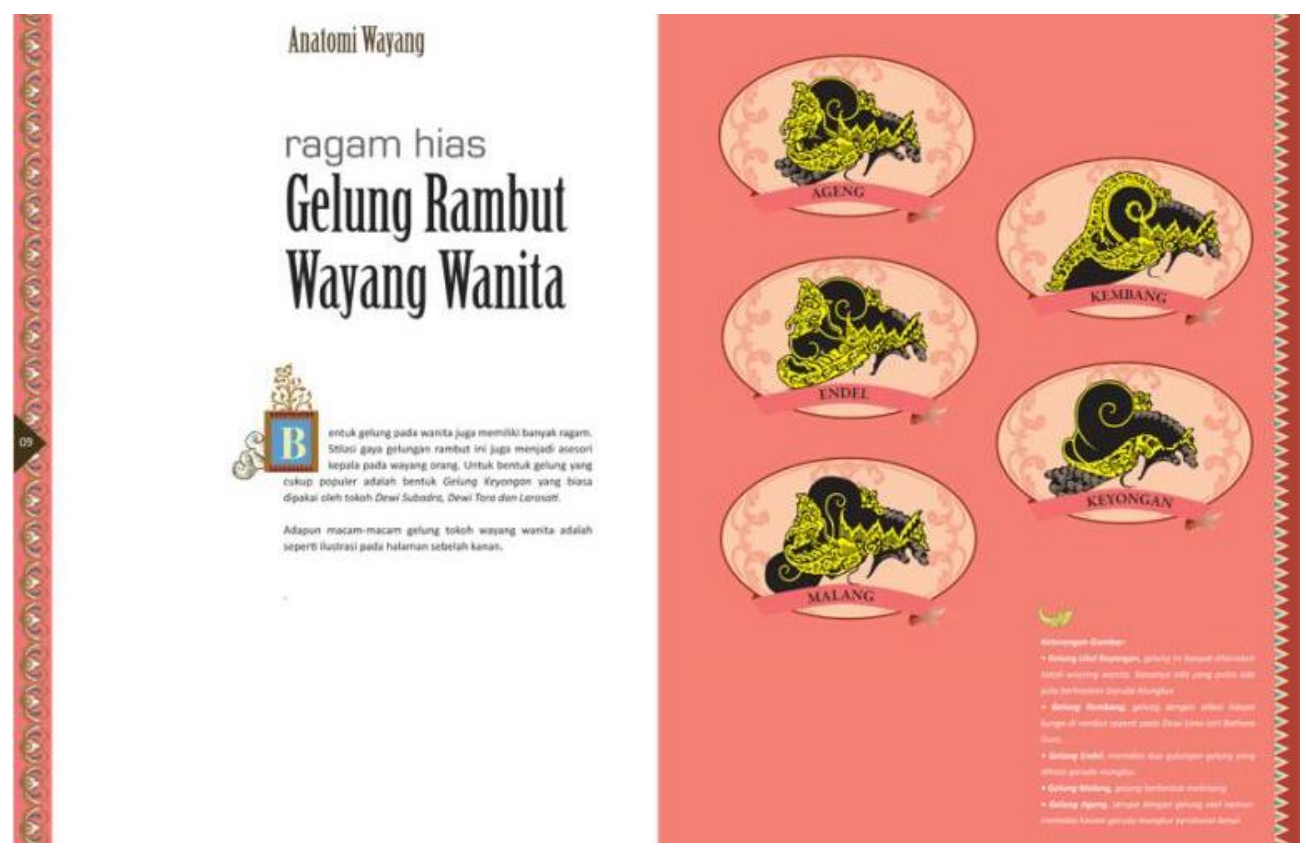

Gambar 12 Bab anatomi wayang yang membahas ragam hias gelung wayang wanita. Sumber: Hasil perancangan tim peneliti

\section{Halaman Aplikasi Asesori Busana (Ragam Hias Jamang Wayang dan Garuda Mungkur)}

Pada halaman selanjutnya masih pada bab Aplikasi Asesori Busana ini dimulai pembahasan ragam hias jamang wayang dan Garuda Mungkur. Jamang adalah hiasan kepala keemasan yang berbentuk seperti segitiga berderet di atas dahi, biasanya terdapat pada wayang kulit purwa dan juga menjadi pakem asesoris pada wayang orang. Ada bermacam bentuk jamang, antara lain:

Jamang Sada Saeler, yang biasa dipakai oleh wayang jenis bambangan seperti putera-putera ksatria yang hidup dipertapaan.

Jamang Sungsun, dengan susunan segitiga yang bersusun ke atas, dalam pewayangan biasanya menjadi ragam hias pada mahkota Raja. (Wangi, 2009) 


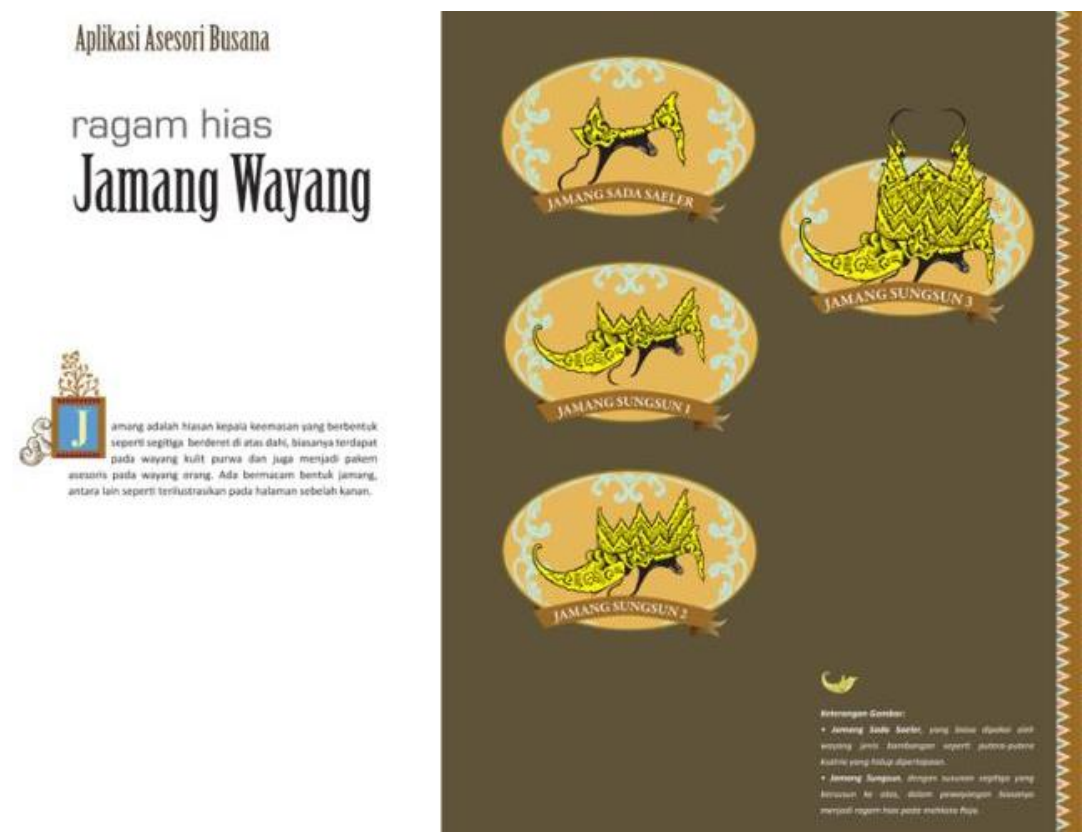

Gambar 13 Bab Aplikasi Asesori Busana Ragam Hias Jenis Jamang Wayang Sumber: Hasil perancangan tim peneliti

Pada halaman ini, masih pada bab Aplikasi Aksesori Busana ini dimulai pembahasan ragam hias Garuda Mungkur adalah hiasan yang melekat pada bagian belakang gelung atau mahkota. Hiasan ini biasanya dikenakan oleh golongan raja, ksatria, para punggawa dan juga patih.
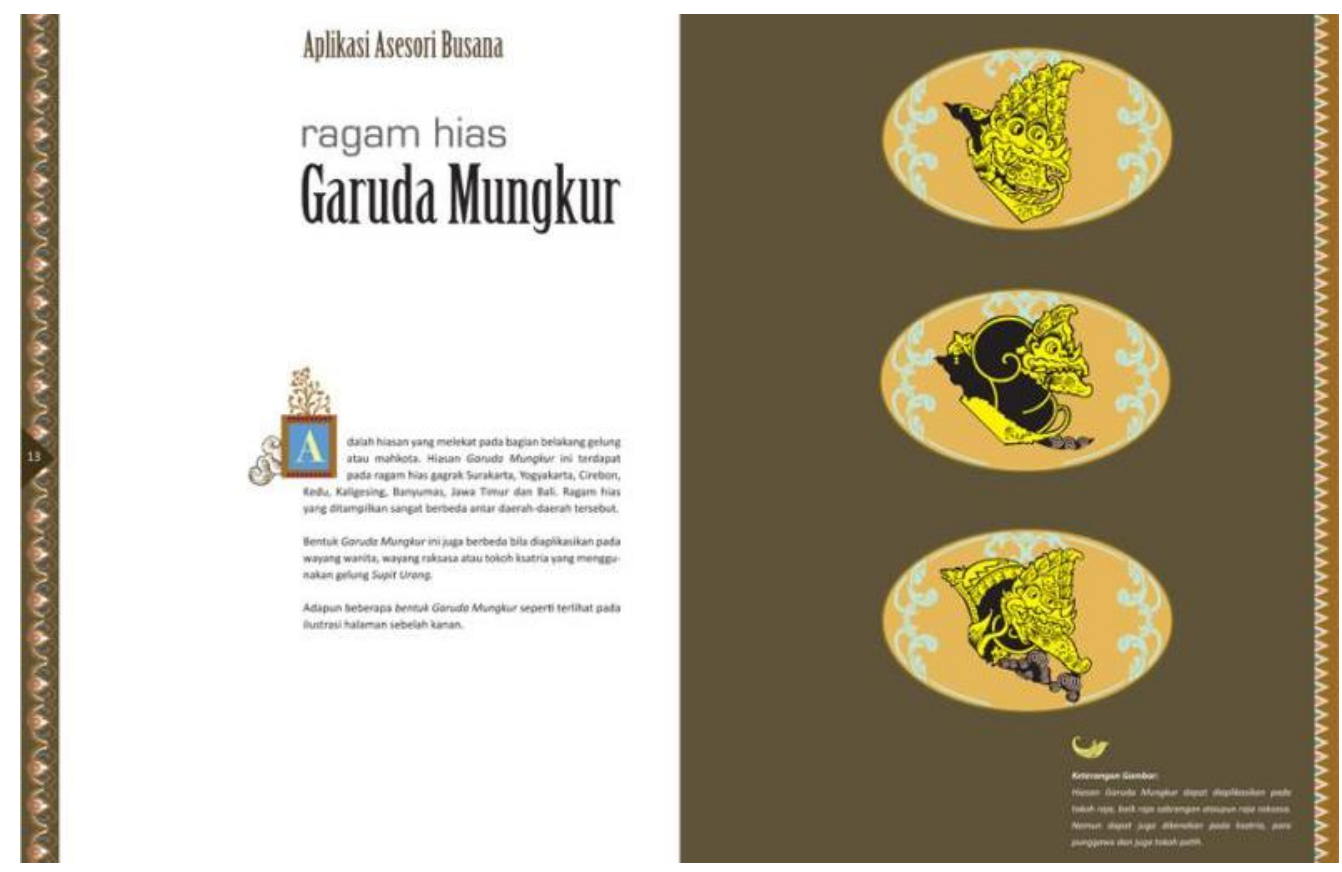

Gambar 14 Bab Aplikasi Asesori Busana

dibahas beberapa jenis ragam hias Garuda Mungkur

Sumber: Hasil perancangan tim peneliti. 


\section{Halaman Aplikasi Asesori Busana (Ragam Hias Irah-Irahan)}

Pada halaman bab ini dibahas beberapa jenis ragam hias Irah-Irahan atau bentuk penutup kepala yang menentukan dari golongan mana tokoh wayang itu berasal. Beberapa jenis penutup kepala adalah:

Makuta, yang juga berarti mahkota adalah penutup kepala yang digunakan para raja dan juga beberapa golongan dewa.

Topong, semacam mahkota namun bulat dan pendek yang digunakan oleh beberapa tokoh raja dan dewa.

Ketu, mahkota sederhana yang digunakan oleh sebagian dewa dan patih.

Sorban Mekena, yang juga dikenal dengan ketu keyongan karena bentuknya menyerupai keong biasa dikenakan oleh beberapa dewa dan resi.

Pogok Blangkon, menyerupai bentuk blangkon biasa digunakan beberapa tokoh punggawa dan buta/raksasa.
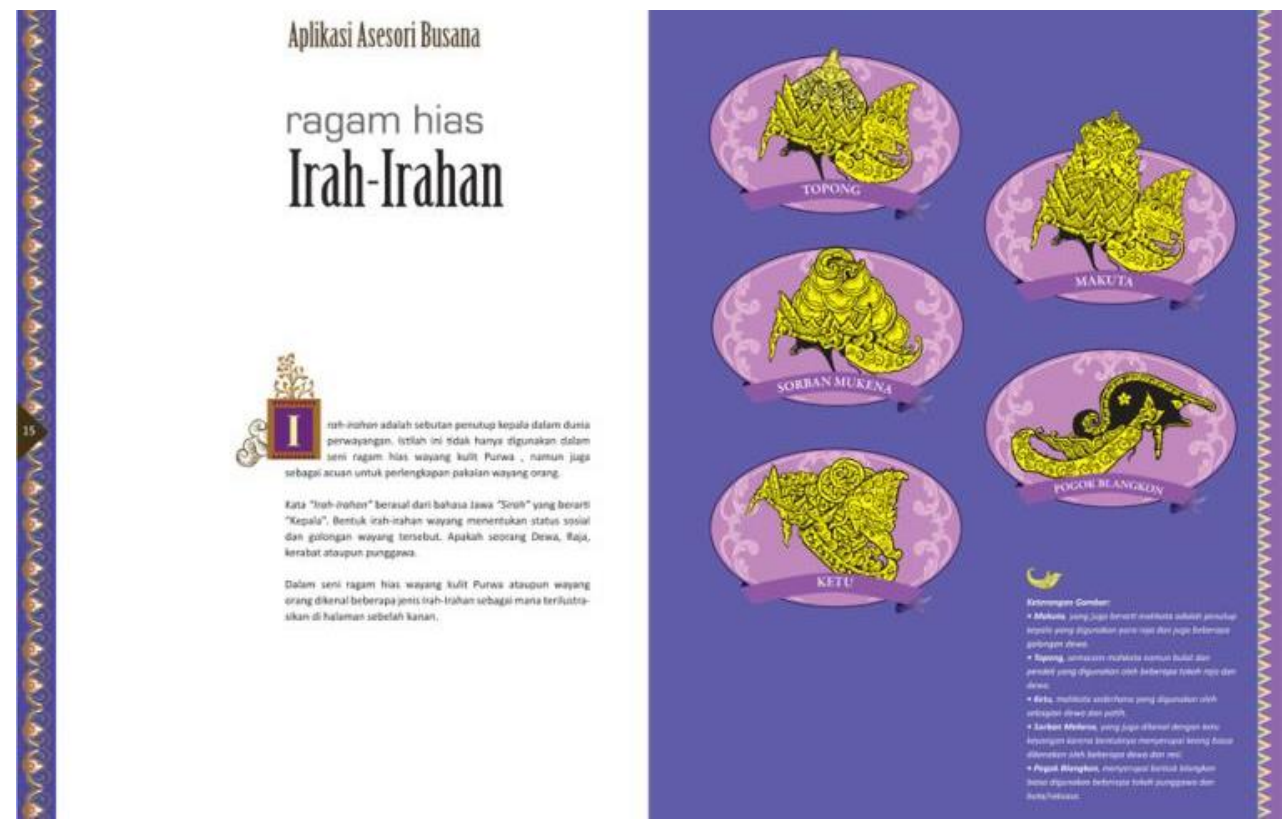

Gambar 15 Bab Aplikasi Aksesori Busana dibahas beberapa jenis ragam hias Irah-irahan.

Sumber: Hasil perancangan tim peneliti

\section{Halaman Aplikasi Asesori Busana (Ragam Hias Kalung dan Kelat Bahu)}

Pada halaman bab ini dibahas beberapa jenis ragam kalung dan kelat bahu dimana masingmasing asesori ini menunjukkan juga status sosial dari pemakainya, adapun kalung terdiri dari dua jenis yaitu:

Kalung kebo manggah (berbentuk melengkung seperti tanduk kerbau)

Kalung tanggalan (berbentuk seperti bulan sabit). 
Kelat Bahu adalah aksesori yang biasa dipakai pada lengan wayang dan diaplikasikan pada wayang kulit dan wayang orang adapun jenis-jenis kelat bahu adalah;

Bogeman atau Candrakirana adalah kelat bahu yang biasanya dipakai oleh tokoh Bima dan Hanoman

Naga Memangsa atau Naga Rangsang adalah kelat bahu yang biasa dipakai oleh raja-raja.

Clumpringan adalah jenis kelat bahu yang biasa dipakai oleh para punggawa (Wangi, 2009)
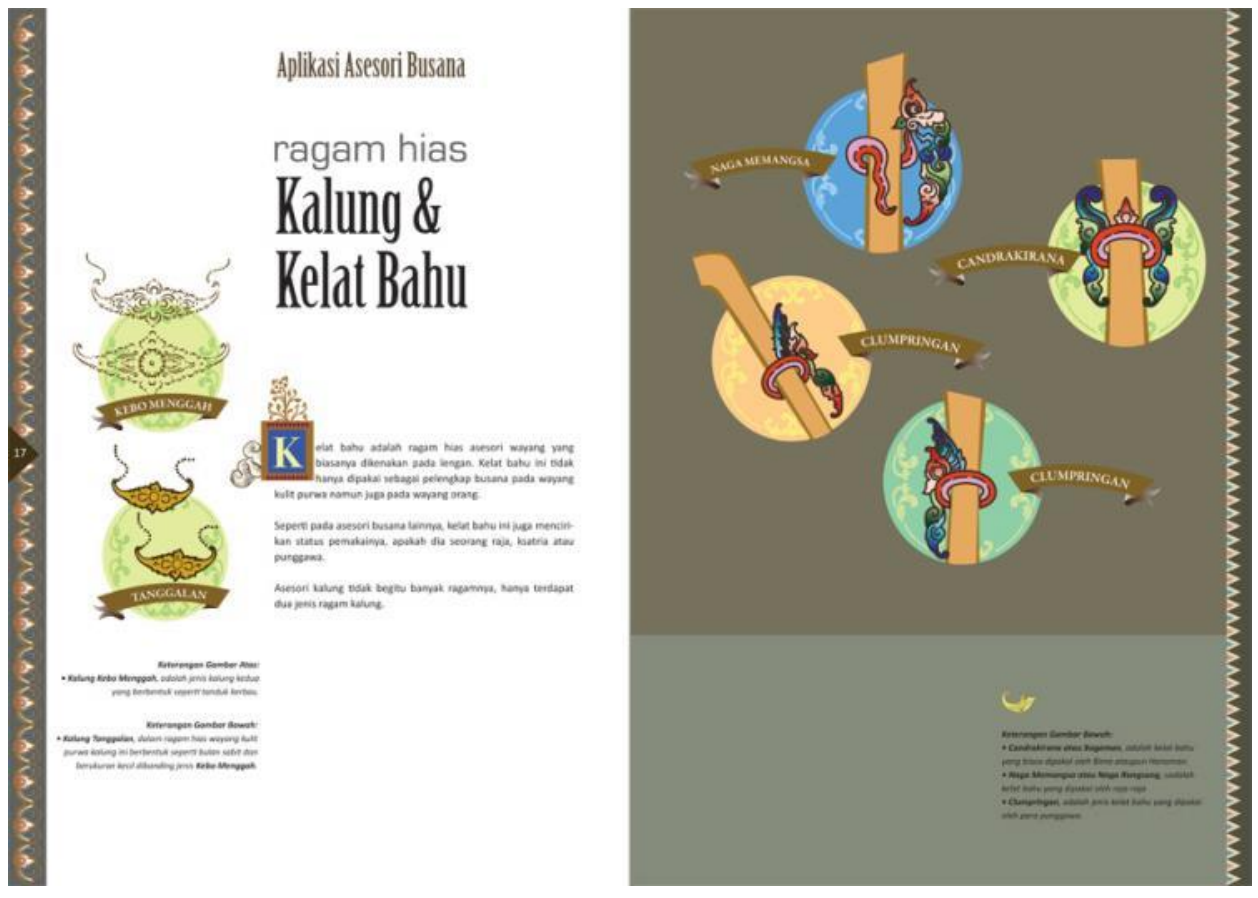

Gambar 16 Bab Aplikasi Aksesori Busana

dibahas beberapa jenis ragam hias Kalung dan Kelat Bahu.

Sumber: Hasil perancangan tim peneliti

\section{Halaman Aplikasi Asesori Busana (Ragam Hias Gelang)}

Berbeda dengan Sumping, aksesoris gelang pada wayang dapat menentukan kedudukan dan karakter tokoh wayang tersebut.

Gelang Kana, biasanya dikenakan oleh seorang ksatria atau seorang putri.

Gelang Candrakirana, hanya dikenakan oleh Bima dan Hanoman.

Gelang Kana Rangkep, dikenakan tokoh pendeta, raja dan juga ksatria.

Gelang Binggel Rangkep, dikenakan tokoh patih.

Gelang Binggel Rangkep Clumpringan, dikenakan khusus tokoh Rahwana 


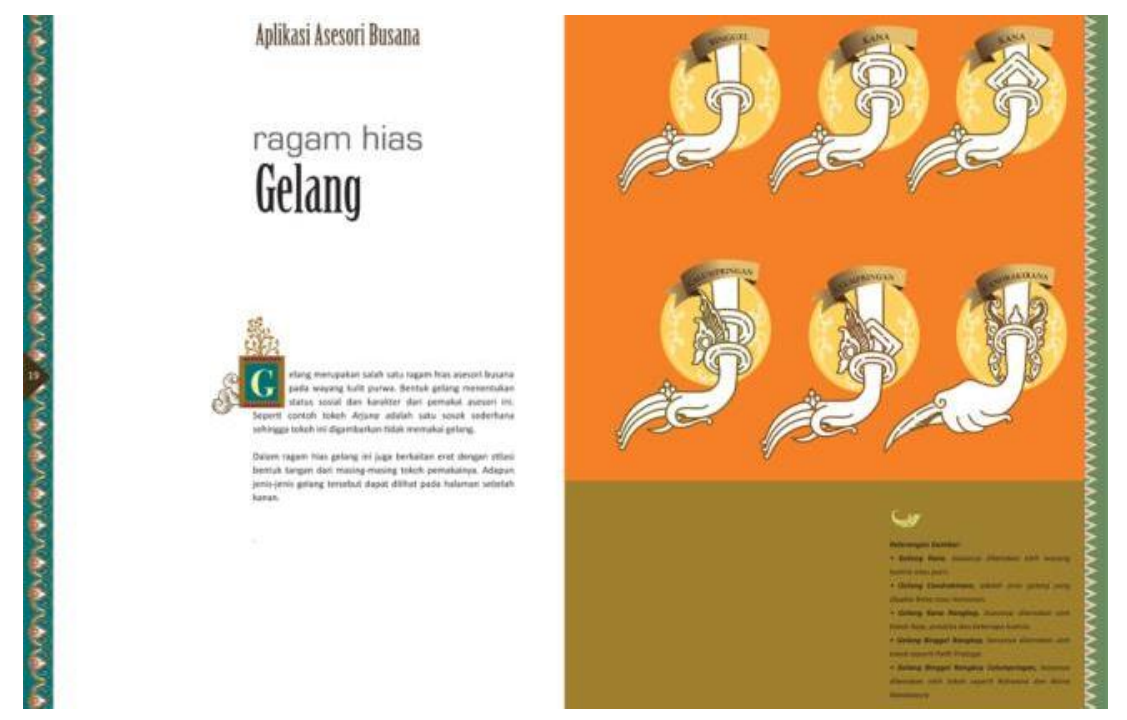

Gambar 17 Bab Aplikasi Asesori Busana dibahas beberapa jenis ragam hias Gelang. Sumber: Hasil perancangan tim peneliti

\section{Halaman Aplikasi Asesori Busana (Ragam Hias Sumping)}

Adalah perhiasan telinga pada wayang dengan beberapa macam jenis sumping. Pemakaiannya tidak dibedakan antara pria maupun wanita serta tidak dibedakan golongan derajat pemakainya. Untuk sumping Gajah Ngoling (belut) khusus dikenakan oleh tokoh Bima.

Ada bermacam bentuk sumping dalam ragam hias wayang yaitu:

Sekar Kluwih, adalah bentuk sumping yang biasanya dipakai oleh tokoh Adipati Karna, Patih Sengkuni, Rajamala dll.

Gajah Ngoling (belut) adalah jenis sumping yang biasa dipakai oleh tokoh Bima.

Waderan adalah jenis sumping yang biasanya digunakan oleh Yudistira, Banowati dan Dewi Drupadi (Wangi, 2009).
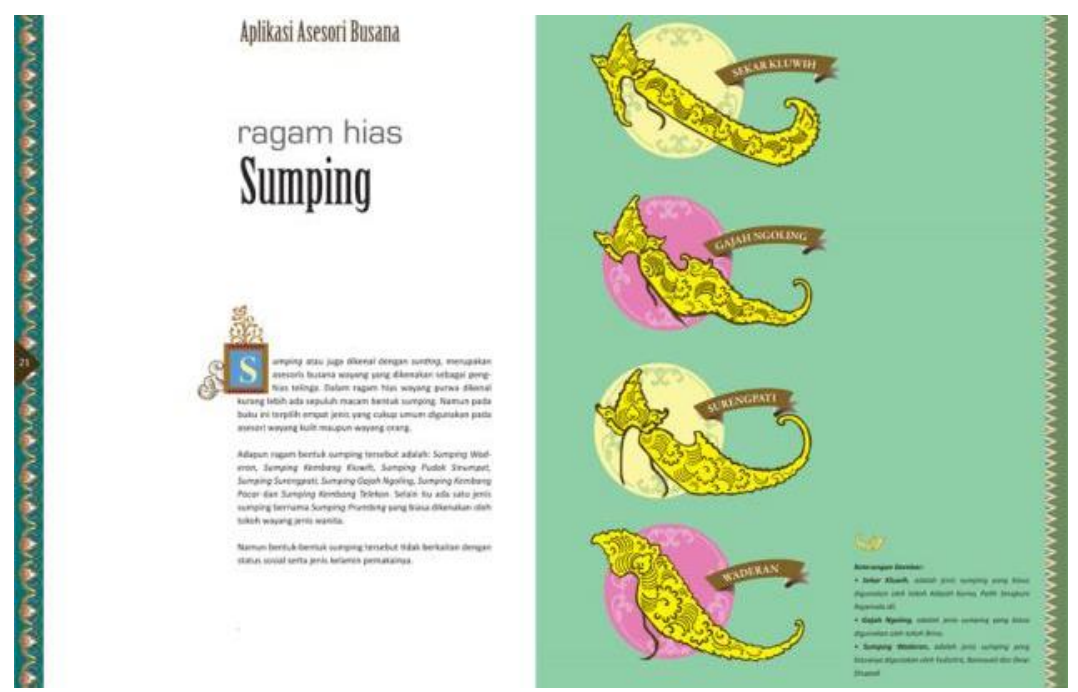

Gambar 18 Bab Aplikasi Asesori Busana dibahas beberapa jenis ragam hias Sumping. Sumber: Hasil perancangan tim peneliti 


\section{Halaman Galeri (Asesori Busana Wayang Pria)}

Pada halaman galeri ini, adalah bab penutup dari buku ragam hias ini dimana ditampilkan beberapa contoh aplikasi busana anatomi wayang pria dan wanita serta sedikit biografi karakter yang ditampilkan tersebut. Untuk tokoh wayang pria dipilih Sri Kresna, adalah termasuk tokoh sentral dalam pewayangan, karena tokoh ini adalah salah satu penasehat Pandawa dan terkenal akan kesaktiannya mempunyai senjata ampuh Cakra dan Cangkok Wijayakusuma. Dalam pembahasan tokoh ini coba untuk ditelaah asesori busana yang dikenakan (Wangi, 2009).

Pada contoh wayang wanita, tokoh yang ditampilkan adalah tokoh Srikandi yang dikenal sebagai wanita tangguh yang memahami ilmu keprajuritan.Tokoh ini adalah salah satu dari istri Arjuna yang pandai memanah karena belajar dari suaminya sendiri.Nama Srikandi cukup dikenal dalam kisah mahabarata karena keberaniannya menghadapi Resi Bisma dalam peperangan besar Baratayudha. Sama dengan tokoh Kresna pada halaman contoh busana wayang wanita ini ditelaah beberapa aksesori wayang yang cukup berbeda dengan aksesori yang dikenakan wayang pria.

Pada halaman terakhir ditampilkan beberapa contoh aplikasi grafis pengambangan dari ragam hias wayang kulit gagrak Surakarta yang menjadi inspirasi desain masa kini. Sejalan dengan tujuan dilakukannya penelitian ini, diharapkan buku ragam hias ini menjadi inspirasi bagi perkembangan ilmu seni dan desain.
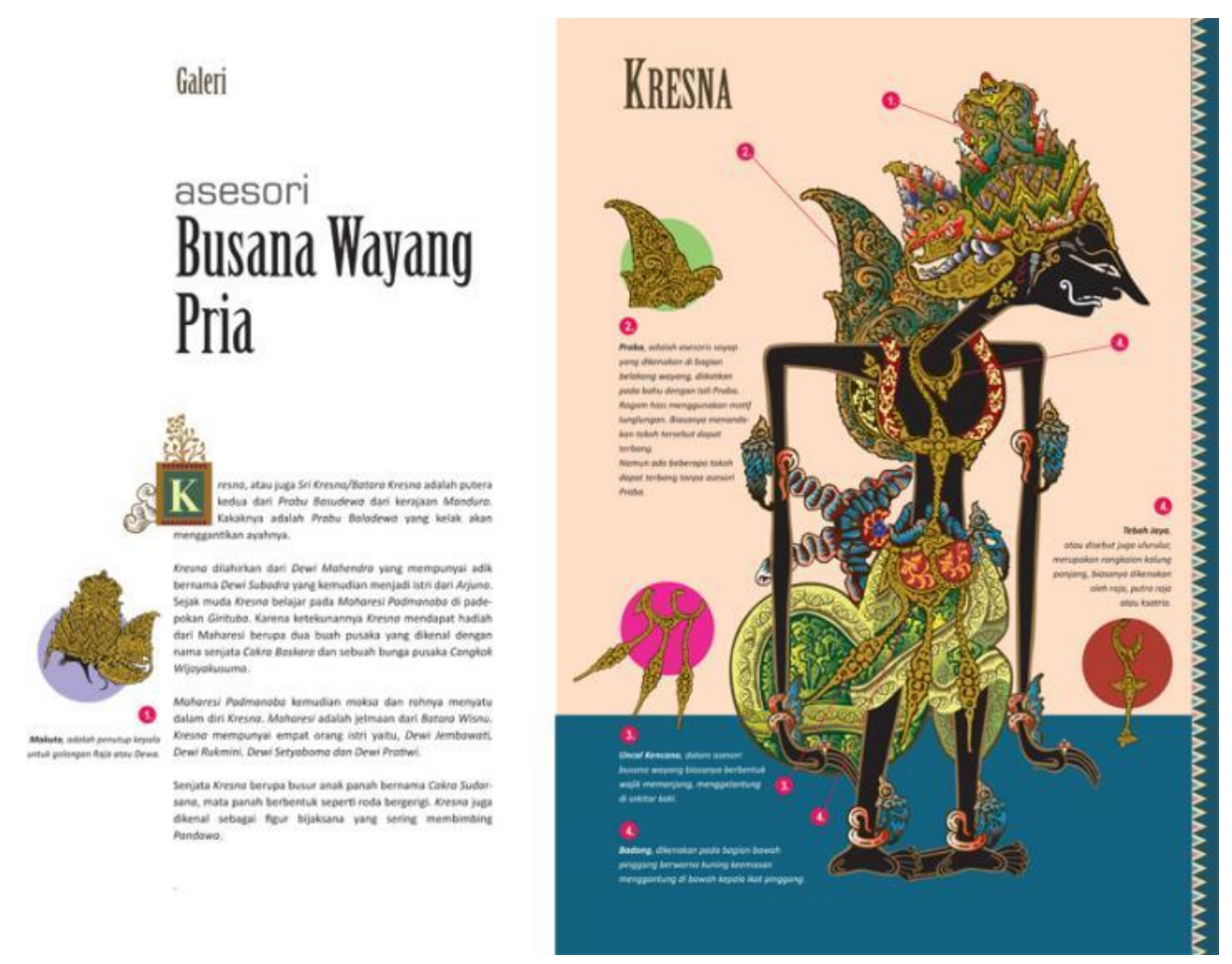

Gambar 19 Bab Galeri dibahas contoh aksesori busana wayang pria (Kresna). Sumber: Hasil perancangan tim peneliti 


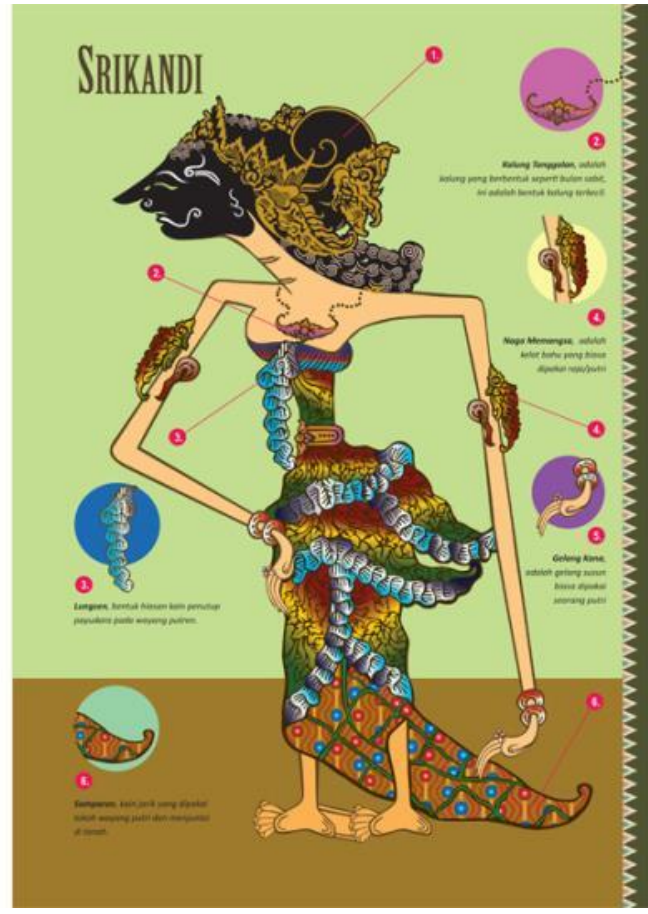

Gambar 20 Bab Galeri dibahas contoh asesori busana wayang Wanita (Srikandi). Sumber: Hasil perancangan tim peneliti
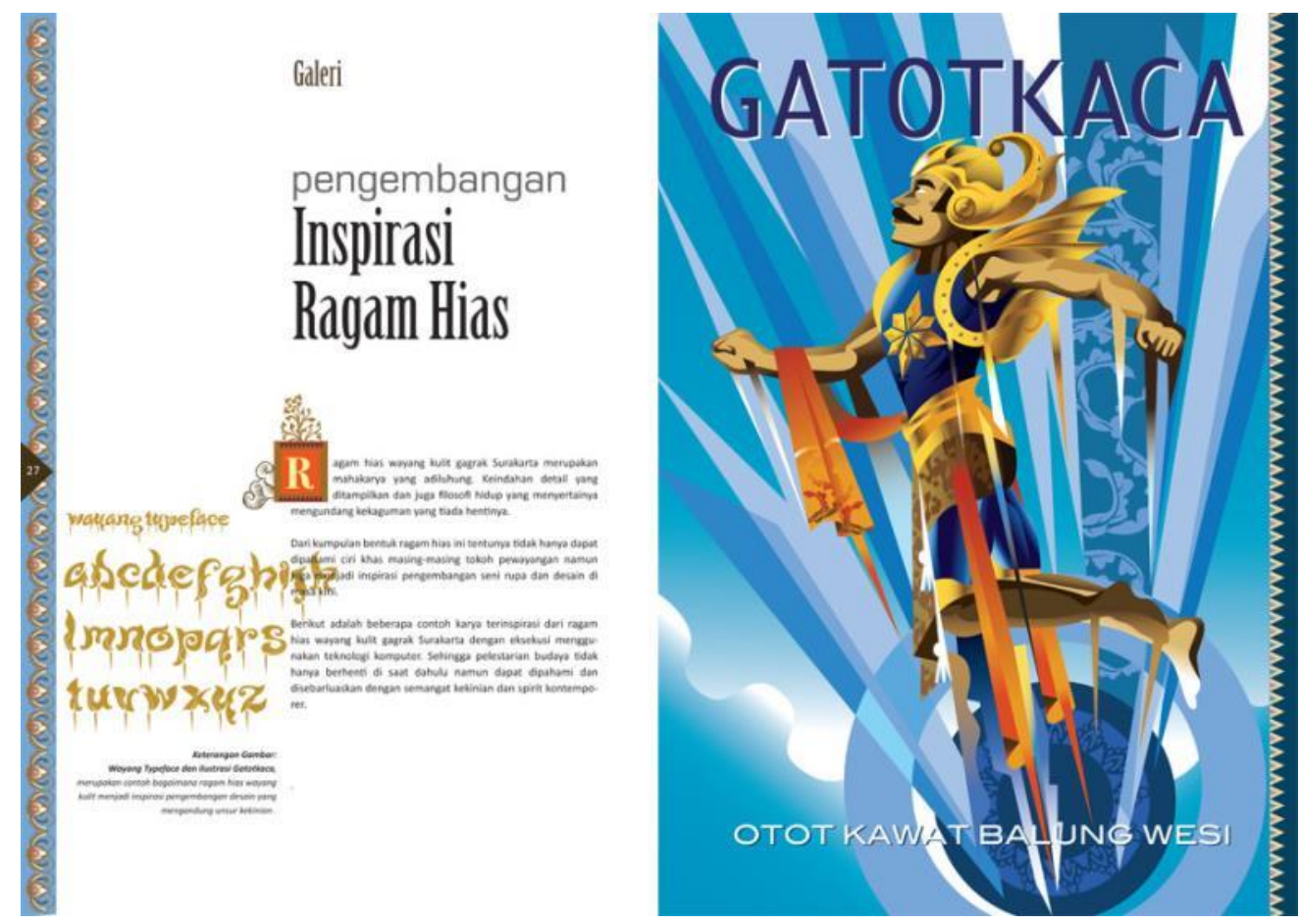

Gambar 21 Bab Galeri dibahas mengenai pengembangan inspirasi ragam hias Sumber: Hasil perancangan tim peneliti 


\section{SIMPULAN}

Sebuah buku ragam hias wayang purwa merupakan sumber inspirasi yang dibutuhkan oleh desainer pada masa sekarang. Minimnya referensi mengenai ragam hias wayang yang dipadukan dengan aplikasi pengembangan yang disesuaikan dengan tren desain saat ini tentunya merupakan sumber inspirasi yang tak ternilai. Ragam hias tidak sekedar keindahan masa lalu, namun kehadirannya pada dunia desain saat ini membangun kembali nilai-nilai agungnya, menggugah potensi ide desainer untuk menciptakan pengembangan baru yang pada ujungnya menambah nilai desain/produk yang dihasilkan.

Penelitian ini bertujuan menggali segala potensi (sejarah, budaya, filosofi, pakem serta isu kekinian tren desain) ragam hias wayang purwa, dan menggunakannya sebagai potensi ide untuk menciptakan produk desain yang memuat pesan local value dalam kemasan kekinian contemporary spirits. Sebuah kumpulan ragam hias dalam gagasan yang diolah dari 'nilai-nilai lama' yang telah ada yang nantinya akan diaplikasikan menjadi 'nilai baru' sebuah karya desain yang dapat diterima secara universal dan global.

Pada hasil penelitian kali ini berupa prototype/dummy buku Ragam Hias Wayang Gagrak Surakarta, tentu belum bisa dikatakan sempurna. Masih banyak kekurangan dalam pengerjaan dan materi yang ingin dimasukkan dalam perancangan buku ini.Namun keterbatasan waktu pula yang menjadi kendala utama dimana proses tracing membutuhkan ketekunan tersendiri. Dengan penambahan support waktu dan tenaga tentunya menjadi kebutuhan utama untuk menjadikan buku ragam hias ini lengkap dan layak terbit.

\section{DAFTAR PUSTAKA}

Piliang, Y. (2006). Pluralitas Bahasa Rupa: Membaca Pikiran Primadi Tabrani. Jurnal Ilmu Desain (FSRD ITB), $1(1)$

Samara, T. (2002). Making and Breaking the Grid. New York: Rockport Publisher

Soetrisno. (2008). Wayang Sebagai Warisan Budaya Dunia. Jakarta: SIC. . (2004). Wayang Sebagai Ungkapan Filsafat Jawa. Yogyakarta: Adita Pressindoesti.

Wangi, S. (1999). Ensiklopedi Wayang Indonesia jilid 2. Jakarta: Sena Wangi. (1999). Ensiklopedi Wayang Indonesia jilid 3. Jakarta: Sena Wangi. . (1999). Ensiklopedi Wayang Indonesia jilid 4. Jakarta: Sena Wangi. . (1999). Ensiklopedi Wayang Indonesia jilid 5. Jakarta: Sena Wangi. 